\title{
1. Clever or bad? Mapping the legal terrain of business delinquency and collusion
}

The opening discussion contained in this chapter maps out the legal terrain of business delinquency. It does so by drawing a major normative distinction between direct, blatant and specifiable acts of taking with economic consequences - theft-like acts - and indirect, artful, less visible forms of economic gain and loss - acts of deception, fraud, collusion and trickery. Much of what now passes as business delinquency and crime falls within that second category, the province of the trickster, fraudster and joker rather than of the thief. As something which is more ambiguous and opaque, this is then a more difficult subject of legal control. This character of business delinquency is elucidated in a number of biographical sketches of bad and tricky business behaviour, which can be used factually to inform a normative discussion. The resulting normative uncertainty within the subject may be seen as the product of complex and often conflicted individual personalities, a significant but complicated organisational context, and an ambiguous perception of business, trade and the economic domain. In short, it is the problem of how to fit entrepreneurship, organisational dynamic and the profit motive into a normative model.

\section{DIRTY DEALING IN THE ECONOMIC DOMAIN}

Crime and misconduct in the area of business activity, and especially in relation to large-scale and transnational business dealings, has become a subject of growing general awareness and increasing concern. The 'global financial crisis' in recent years has served to dramatise the harmful consequences of business behaviour and transactions and excite public agitation regarding an apparent inability on the part of governments and formal legal systems to grapple effectively in political and legal terms with the underlying causes, the symptoms and the consequences of dirty dealings in the marketplace. There is a wide sense of frustration and helplessness in the face of what appears to be a potent mixture of systemic malaise and dysfunction and amoral and reckless conduct on the part of powerful individuals. Such is the strength of 
the critical rhetoric directed at bad business behaviour that an increasing resort to the powerful mechanism of legal control via criminal law might seem both justifiable and necessary. But the employment of a range of legal sanctions in this context appears increasingly problematical. Two examples may serve to demonstrate the complexity and diversity of political and legal responses. First, it was revealed in July 2016 in a US congressional report that in 2012 an official decision was taken in the USA, responding in particular to UK government concerns, not to prosecute a major bank HSBC in relation to alleged money-laundering activities for fear of provoking a 'global financial disaster'. ${ }^{1}$ Second, however, at much the same time the EU Commission decided to suspend payments to Greece of some regional development funding, following the Greek Competition Authority's investigation of a major cartel in the construction industry in Greece. ${ }^{2}$ There is a complex and not always consistent cocktail of political, legal and economic argument and strategy in such significant contemporary examples of dirty dealings in the financial, commercial and industrial sectors.

In such a light, the main purpose of this study is to work out a coherent basis in law and policy for the regulation of delinquent business practice and behaviour, through a better-informed understanding of collusive, exploitative and damaging strategies and conduct, whether individual or systemic in nature, on the part of business actors. The ultimate goal is to establish a persuasive justification for legal intervention, especially by means of criminal law and sanctions, in the corporate and business domain. But first it would be useful to clarify the nature and extent of the problem by describing and delineating what is understood by this idea of misconduct and dirty dealings in the economic sphere - and what might qualify as bad business.

\section{PROBLEMS OF DESCRIPTION AND VOCABULARY}

This is in the first place a matter of descriptive vocabulary, of how best to indicate in short terms the nature and scope of the subject matter. And this is also importantly a matter of disciplinary perspective. A law person, for example, might be tempted to talk in terms of illegal or even criminal behaviour, leading eventually to a categorisation as 'economic' or 'business crime'. But that

1 US Senate, Permanent Sub-Committee on Investigations, US Vulnerabilities to Money-Laundering, Drugs, and Terrorist Financing: HSBC Case History, July 2012. See also Lawrence A Cunningham, 'Deferred Prosecutions and Corporate Governance: An Integrated Approach to Investigation and Reform', 66 (2014) Florida Law Review 1.

2 See House of Commons, European Regional Development Fund, Second Report of Session 2012-13, HC 81, July 2012. 
would be to anticipate and beg the important normative question referred to above, of when and how to use criminal law or other methods of regulation to what extent and in what way should such practice and conduct be regarded as illegal? Social scientists and criminologists might prefer the nomenclature of 'deviance', 'delinquency' and 'white-collar crime', but these are concepts which relate uncertainly across the borderline of moral badness and normative non-compliance as an empirical phenomenon. 'Misconduct' may be a safer but too general kind of descriptor. The metaphor of bad conduct perpetrated by 'men in suits' (again, 'white collar') skews the discussion towards a preferred analysis in terms of gender and class. Colloquial language, such as 'dirty dealings in the marketplace' or 'dodgy business' or 'sly tricks', convey quite an accurate sense of the subject as well as its inherent ambiguity and slipperiness, but tend to substitute colourful description for more analytical categorisation. Therefore, the conundrum of a nice and neat title endures, but also then serves to justify a work of this kind which starts from the proposition that there is a missing jurisprudence at the heart of the discussion and that such discussion would be clearer and more productive if such a normative theory were to be agreed and established. For present purposes, on the basis that there is a strong general sense of something which breaches norms of a kind and is damaging in its outcome, the term 'delinquent' will often be used as a working description, as the search proceeds for an appropriate normative response.

In terms of the kind of conduct comprising 'business delinquency', it should be recognised that many observers would draw a distinction as between this and 'traditional' or 'classic' criminal law, which is concerned with violence, aggression, force and targeted damage, or 'street crime' as a cruder criminological description. Underlying this kind of distinction is the characteristic of 'street crime' as having a naked or blatant quality, whereas what qualifies much of the time as business delinquency is much less obvious, below the surface - 'underhand', as a matter of trickery, duping and cheating. At this stage therefore it may be worth saying some more about the descriptive vocabulary of bad business behaviour and its etymology and metaphorical content, in order to inform subsequent discussion.

Broadly speaking, some distinction lies between illegality or criminality which is open and blatant on the one hand (such as theft and robbery) and that which is deceptive and less obvious on the other hand (such as fraud and deception). Is this an important and relevant difference? Many contemporary legal systems would equate the two types of offending as a matter of criminality. Thus English criminal law ranks theft and deception similarly in terms of 
their seriousness and liability to sanctions. ${ }^{3}$ But, as will be seen further below, there are important practical and conceptual differences and also some historical dissent regarding the badness of fraud and deception, expressed in the famous judicial comment which reserved judgement on conduct which made a fool of another ${ }^{4}$ and also underlying the principle caveat emptor. ${ }^{5}$ As Cerian Griffiths has recently commented:

The great definitional ambiguity at the heart of cheating was as true 300 years ago as it is today. As a collection of offences, cheating and fraud are ontologically problematic. Fraud offences exist at the interface of civil law and criminal law and this interconnectedness results in fraud and financial misconduct often being viewed with ambivalence in the twenty-first century. ${ }^{6}$

How have societies regarded the 'sharp', 'cunning', 'sly' and even 'clever' trickster compared to the more 'brazen' thief or robber? Consider the whole range of descriptive language in English used to convey the idea of the trickster: swindler, cheat, rascal, scoundrel, rogue, knave, scamp, some of which is suggestive of grudging admiration and affection, and literary characterisation such as the Knave of Hearts. ${ }^{7}$

Underlying this diversity of language, there are some important distinctions of both context and effect which may usefully be flagged up at this early stage, and these also underpin the respective metaphors and imagery of 'crime on the street' and 'crime in the suites'. This can also be expressed as a difference between conduct which is open and physical, and that which is obscure and intellectual.

3 For the basic offences, for both a maximum term of imprisonment of ten years: Theft Act 1968, s 7; Fraud Act 2006, s 1(3).

4 The statement, attributed to Lord Chief Justice Holt that the Court would not 'indict one Man for making a Fool of another', in Jones (1703), 2 Ld Raymond 1013. See the discussion by Simon Stern: 'R v Jones (1703)', in Philip Handler, Henry Mares and Ian Williams (eds), Landmark Cases in Criminal Law (Hart, 2017), ch 4.

5 The principle that the buyer takes the risk regarding the condition of property or goods being purchased and has the responsibility to check this matter.

6 Cerian Griffiths, 'The Honest Cheat: A Timely History of Cheating and Fraud Following Ivey v Genting Casinos (UK) Ltd t/a Crockfords (2017) UKSC 67', 40 (2007) Legal Studies 252, at 256. See also J P Locker and B Godfrey, 'Ontological Boundaries and Temporal Watersheds in the Development of White-Collar Crime', 46 (2006) British Journal of Criminology 976.

7 Lewis Carroll, Alice's Adventures in Wonderland (Macmillan, 1865), chs $8 \mathrm{ff}$. 


\section{OPEN THEFT AND HIDDEN FRAUD}

Conduct legally characterised as theft or robbery is typically perpetrated in an open space and involves a physical process, a forcible act of taking something. Conduct which is legally characterised as fraudulent or deceptive tends by its nature to be much less visible and to comprise a mainly intellectual process. The first then seems more straightforward than the second, and easier in terms of evidence and interpretation - action is louder than words, plainer than thoughts. The context of carrying out these respective forms of conduct suggests a difference in situational complexity - fraud needs to be more carefully crafted than theft and this may suggest different personal qualities on the part of the respective perpetrators, for instance the ability and willingness to use physical force as distinct from the ability to fashion and implement a cunning plan. Both may require criminal qualities, but of a different order - 'the joker' and 'the thief'. ${ }^{8}$

This difference was described graphically in the film Carlito's Way $^{9}$ in its exploration of the shift from and relation between 'street' and 'white collar' criminality. In the narrative of the film, a notorious and serious street criminal (Carlito Brigante) tries to go straight while his skilful defence lawyer (David Kleinfeld) moves into serious crime. Brigante to Kleinfeld:

You ain't a lawyer no more, Dave, you're a gangster now. On the other side. A whole new ball game. You can't learn about it in school, and you can't have a late start. ${ }^{10}$

This comment is suggestive of key distinctions - a different ball game, involving different methods, different kinds of ability, relating to experience and personality and learned in different ways. White-collar crime may be a matter of schooling, whereas street crime has to be learned out there on the streets, and that might imply certain differences in social background and experience as well as temperament and intellect. Both may require skill, but skill in using weapons or hands may be different from the skill used in drafting a clever plan.

Added to this is the fact that a clever plan may also be the very fare of business, politics or professional life, leading to the thesis that these roles may be in some respects criminogenic, at least in relation to white-collar delinquency - that for instance business persons and political actors have a natural tendency

8 'There must be some kind of way outta here, Said the joker to the thief': Bob Dylan, 'All Along the Watchtower' (1967). 'Joker' here is being used in the sense of playing a joke as something clever and not the expected reality, a kind of game.

9 (Dir. Brian de Palma, 1993).

10 Ibid. 
to conspire, collude and dissemble. This calls to mind Adam Smith's notorious dictum (which was a matter of empirical observation rather than judgemental) that 'people in the same trade seldom meet together ... but the conversation ends in a conspiracy against the public, or in some contrivance to raise prices'. ${ }^{11}$ Indeed, this perception has been further elaborated as criminological theory, as David Nelken has argued:

A central debate amongst scholars of white-collar crime in fact concerns the extent to which corporate and business crime should be seen as an inevitable consequence of capitalism ... We should not underestimate the fruitfulness of hypotheses based on the capacity of capitalism to generate business crime. ${ }^{12}$

And this argument may be taken a stage further - that success and achievement in business, political activity and even professional work such as that of the lawyer may depend on clever planning, feint and subterfuge as much as plain speaking, and in the words of Lewis Hyde:

Thus is trickster and thus is polytropic man, shifty as an octopus, coloring himself to fit his surroundings, putting on a fresh face for each man or woman he meets, charming, disarming and not to be trusted. (He makes a good politician, especially in a democracy, where many voters call for many faces. $)^{13}$

This leads to an interesting thought: that stratagems of fraud may possess a wider value and utility, whatever moral doubt might arise. The underlying question of the extent to which certain kinds of bad practice (including fraud) may be endemic in the practice of business will be explored in detail in Chapter 8 .

\section{EFFECT: MATERIAL LOSS AND LOSS OF OPPORTUNITY}

The matter is still debated, and so still rather indeterminate of the relative impact and effect of 'open theft' and 'hidden fraud'. The former may be more immediately disturbing and distressing, yet the second has an insidious char-

Adam Smith, The Wealth of Nations (1776), Book 1, ch 10.

12 David Nelken, 'White-Collar and Corporate Crime', in The Oxford Handbook of Criminology (5th edn, Oxford University Press, 2012), ch 21, pp 637-8.

13 Lewis Hyde, Trickster Makes This World (Canongate, 2008), p 53. 
acter. The question was put up for debate by Jonathan Swift - his Lilliputians considered the matter:

They look upon fraud as a greater crime than theft, and therefore seldom fail to punish it with death: for, they allege, that care and vigilance, with a very common understanding, may preserve a man's good from thieves; but honesty have no fence against superior cunning; and since it is necessary that there be a perpetual intercourse of buying and selling, and dealing upon credit; where fraud is permitted and connived at, or have no law to punish it, the honest dealer is always undone, and the knave gets the advantage. ${ }^{14}$

But the debate here is partly a matter of sensibility. The victim of theft or robbery quickly and easily feels the impact of the loss - in that sense, it is clean and certain. On the other hand, the victim of deception may not be so sensitive regarding a loss which is obscure, diffuse and difficult to assess more exactly. Contrary to the thrust of Swift's argument, the following may be imagined as an exploration of damage arising from a secretive price-fixing offence. Consider the following dialogue between a policymaker and an end consumer of a product:

Policymaker: Are you not outraged by this price-fixing activity?

Consumer: Why should I feel that way?

Policymaker: Because you have been duped into paying a higher price.

Consumer: Oh? really? I wasn't aware of that - it didn't feel like it was hitting me in the pocket. Are you sure?

Policymaker: Without a doubt. An economist can prove to you that in a situation of true price competition you would have paid 10 per cent less.

Consumer: Oh - I'm not sure if I can follow the maths there. But I know that times are hard and if the suppliers had not been able to maintain those higher prices, some of them would have gone out of business, and that would have reduced my choice. That's what some of my friends who work in the retail business tell me.

Policymaker: That's a rather silly thing to say. I don't think you appreciate how the price-fixing is so offensive to the open market ideology that is designed to protect your interests.

Consumer: Are you patronising me with your neoliberal cant and trying to turn me into a victim?

14 Jonathan Swift, Gulliver's Travels (Benjamin Motte, 1726), Part 1, ch VI. 
There is of course an element of caricature in this encounter, but it is intended to show how the offending conduct is a matter of politico-economic and legal construction in both its definition and its effects. Then, returning to Swift's depiction of deceptive offending and its extreme censure among the Lilliputians, it should be appreciated that what is presented there is very much in the context of an economic and trading process. Placing the effect of deception in that kind of context helps to specify the objection to such conduct, distinguishing for instance the 'white lie' kind of deception in interpersonal relations, which may be based on a benign or protective intent. In the economic domain, deceptive practice is likely to be motivated by a prospective profit achieved through a material loss on the part of others. In the argument of Simester and Sullivan, deception in this economic context 'can be seen as an attack on the victim's entitlement to dispose of his property by his own full and informed choice' ${ }^{15}$ and 'understood in this sense, is a crime partly because it entails the manipulation or exploitation of another'. ${ }^{16}$ This kind of justification for legal intervention and control is also linked to the emergence of modern capitalist society within which the opportunities for subtle manipulation of the property rights of others, whether through deceptive strategies or trading (for instance via handling and laundering), have multiplied significantly. ${ }^{17}$ In this way, the effects may not be obvious in terms of visibility and sentience, and may be dispersed and longer term, but can be convincingly expressed as damaging to economic structure, market health and longer-term fair distribution of economic goods. There was a sense of this in Jeremy Bentham's argument that without law there is no security, and so then no abundance, and not even a certainty of subsistence, and the only equality that can exist in such a state of things is an equality of misery. ${ }^{18}$

Following this kind of analysis, it would be useful for the present to note such ideas as the fair distribution of economic goods as an underlying ideal, and conversely the manipulation and exploitation of the economic process as important distinguishing elements of dirty dealing in the economic domain. Or as another way of expressing this perception, it could be said that types of theft result in a material loss, whereas types of fraud result in a loss of opportunity.

\footnotetext{
15 An entitlement rooted of course, in a capitalist and property-owning society, and in that sense seen as such as an element of Western but not some other cultures.

16 A P Simester and G R Sullivan, Criminal Law: Theory and Doctrine (2nd edn, Hart, 2003), p 514.

17 Ibid., pp 479-80.

18 Theory of Legislation, Collected Works (University College London, 1968).
} 


\section{NARRATIVES OF BAD BEHAVIOUR: CONCEPTUALISATION AND ORDERING FROM BIOGRAPHY}

Thus, the subject matter of this discussion is known and understood in very broad terms, and is sometimes a matter of detailed reporting and description, but is less easily defined and analysed in exact terms and categorised with certainty. One problem is that there are many different ways of misbehaving in the marketplace, and much depends on facts and context, so that precise classification and ordering for legal or other purposes of discussion and agreed final versions and definition remain elusive. Take a broad business context and select a range of dishonest, deceptive, manipulative and exploitative practices and a broad picture will emerge. But by its very nature the subject is factually shady and difficult to interpret, apart from the relatively few historical examples which, for whatever reason, have been exposed as criminal cases or media-projected 'scandals', when official or unofficial investigation has revealed the detail of the activity in question and the main protagonists, whether individual or corporate. In these latter cases there may be a wealth of data, arising from official and legal processes, then documentary (or 'factual') secondary reportage and analysis, and then sometimes as well subsequent semi-fictional or wholly imagined and fictional accounts in literature and dramatised presentation.

Discussion can then draw upon formal and verified documentation, informal but still perhaps reliable records, expert interpretation and analysis, and then written and other dramatisations, which may be well informed and perceptive, but provide a further layer of reimagining the subject. Inevitably those discussing and studying the subject tend to base themselves on 'famous cases' and the account then provided is biographical, of certain people and certain kinds of activity. This may be thought of as a biographical or narrative method. ${ }^{19}$

A notable example of such description and discussion of the subject matter is Maurice Punch's seminal work, Dirty Business, published ${ }^{20}$ in the middle of the 1990s, but still a valuable route into the subject, as a discussion with a detailed factual basis but also as a conceptualisation and ordering of the topic, as indicated in its subtitle, Exploring Corporate Misconduct-Analysis and Cases. In that title, Punch determined the parameters of his study, empir-

19 See, for instance, Harding and Edwards's study of the impact of anti-cartel sanctions (Christopher Harding and Jennifer Edwards, Cartel Criminality (Ashgate, 2015)) as an example of such a biographical approach, through the selection of a number of 'cartel biographies' as actual histories of business conduct.

20 Maurice Punch, Dirty Business: Exploring Corporate Misconduct-Analysis and Cases (Sage, 1996). 
ically, conceptually and in disciplinary terms ('corporate misconduct'), and then his methodology, as an analysis through a case or biographical narration. His approach is worth emulation, so that as the present writers we may set out our terms of reference (although in doing so attempt to elaborate further the idea of corporate misconduct) and our method, which will again draw upon a biographical presentation of historical instances. A glance at the contents list of Dirty Business will indicate the heart of Punch's study in an account of 'ten cases of corporate deviance', as the raw material for much of his analysis and argument. Punch's selection of cases enables the discussion to explore a number of business contexts, while detailing a range of strategies and legal classifications (such as fraud, dishonesty, cheating, collusion, conspiracy, manipulation and intimidation), indicating overall a rich diversity of activity. That diversity in turn presents a challenge to regulation and legal control.

For present purposes, it would be helpful at this stage to replicate briefly Punch's approach just to indicate quickly to the reader the scope and nature of the subject under discussion - corporate deviance, business delinquency or whatever label might be chosen - at this point in history. This may be done conveniently by describing a small selection of well-established and documented cases as a cross-section of the subject. The method is therefore one of summary biography, constructing a typical 'rogues' gallery'.

\section{BIOGRAPHIES: A ROGUES’ GALLERY}

\section{William Chaloner (d.1699)}

William Chaloner ${ }^{21}$ was a celebrated late seventeenth-century criminal and trickster whose career comprised a list of cheating offences, coupled with an exploitation of the criminal justice process as an informer. His early attempts to establish himself as a skilled metal worker were frustrated by the restrictive Guild system and he drifted into a lucrative career as a counterfeiter of coins, lacquered furniture, supplier of dildoes and fake medicines, and a forger of early bank notes. Within that trade he was regarded as a skilled counterfeiter and eventually established for himself a grand lifestyle. At the same time he became adept at betraying both fellow offenders and alleged Jacobite plotters to the authorities while evading detection himself. These latter skills were demonstrated in his manoeuvres with the thief taker Thomas Coppinger, a series of accusations and denunciations and counter-accusations, Chaloner

21 See generally on Chaloner: The Oxford Dictionary of National Biography, entry for William Chaloner by Paul Hopkins and Stuart Handley (Oxford University Press, 2004). 
winning this informers' contest, consigning Coppinger to conviction and execution in 1695 . He was instrumental in bringing a number of his own pupil coiners to justice, benefiting then from an informal immunity on his part.

Typically, Chaloner employed his own skills as a coiner to recommend legitimately to the House of Commons proposals to deal with the problem of debasement of coins, and internal malpractice in the Royal Mint. He had also, unsuccessfully, applied to the Privy Council for a patent to make a new kind of alloy coin. Generally, his career testifies to a hinterland of legitimate and illegal activity within the domain of coinage and public money production at the time. Chaloner was much of the time both a blatant criminal and a collaborator with public authority, to whom his knowledge and experience had value. His nemesis proved to be a combination of his failure to negotiate a pardon in 1696 and the appointment of Isaac Newton as Warden of the Mint. ${ }^{22}$ Newton was committed and zealous in his mission to reform and clean up bad practice in the Royal Mint and appears to have made Chaloner one of his main targets. He succeeded in constructing two cases involving capital felonies against Chaloner, with a large body of witness testimony, and Chaloner was convicted and executed in March 1699.

A review of Chaloner's career provides insight into a seventeenth-century landscape of public money production linked to an illegal enterprise of counterfeiting, forgery, collusion and exploitative immunity. In summary, he was an enterprising operator within the circumstances of his time - a coinage system which was in some turmoil, and a process of criminal law enforcement which relied heavily on entrapment, witness testimony and private rewards. Chaloner's own involvement appears to have been nicely summarised in a contemporary biographical comment: he was 'a Man, who had he squar'd his Talents by the Rules of Justice and Integrity, might have been useful to the Commonwealth; But as he follow'd only the Dictates of Vice, was a rotten member cut off'. ${ }^{23}$

\section{Thomas Cochrane (1775-1860)}

From an aristocratic background, Cochrane's early career was in the royal navy, where he rose from midshipman to commander, and was soon famed for his daring and clever strategies. In popular parlance he was known as 'Sea Wolf' or 'Loupe des Mers'. Commander Cochrane became popular with the

22 Thomas Levenson, Newton and the Counterfeiter (Faber and Faber, 2010); Michael White, Isaac Newton: The Last Sorcerer (Fourth Estate, 1997), pp 269-70.

23 Guzman recidivivus: a short view of the life of Will. Chaloner, the notorious coyner, who was executed at Tyburn on Wednesday the 22d of March 1698/9 (1699). 
British people for his naval exploits but he was also outspoken and ready to attack the government and other leaders for what he thought was their folly and unfair policy. His mind was ever active, considering not only battle tactics, but also affairs of state, and how to improve the condition of ships and working in coal mines. He might be described as a flamboyant intellect, clever and inventive, but a political rebel, and was one of the Radical Whigs.

While Commander Cochrane was at the height of his military renown he joined with some others in a stock exchange speculation. Taking advantage of a rumour that Napoleon Bonaparte had died, a group of merchant gamblers bought and sold their investments at huge profit. But the rumour was false and some people saw this as a scandal and fraud. Then Cochrane's enemies brought an accusation: that he had met privately with the false rumour-monger, and that he was close to the criminal fraud.

In this way the naval hero was brought to trial in 1814. There the issue turned upon the identity of a man seen to be in conference with the Commander, and the colour of his coat. This was a matter of uncertainty. Some witnesses said that it was green, others that it was red. There was little else on which to determine the charge. But the judge was hostile towards the defendant and urged that there should be a finding of guilt. So that was the verdict, and the judge decreed the sentence: 12 months in prison, a fine of $£ 1000$, and an hour in the pillory in a prominent site in London. At the same time, the Commander was deprived of his naval rank and honours, and expelled from Parliament, to which he had been elected as one of the members for Westminster. Moreover, his banner was kicked out of Westminster Abbey. But there was a wide degree of public scepticism regarding the verdict. Some people came together to raise money for the fine, the Commander was quickly elected again in Westminster, and his fellow MP, another Radical Whig, threatened to stand with the Commander in the pillory if he was placed there. Fearing that the crowd would riot in support of the Commander if he was put in the pillory, that strategy was abandoned. And then the Commander, using his practical tactics, escaped from the jail.

Cochrane soon left the country to lead the naval forces in the wars of independence from Spain in the Southern Americas. Again, he proved to be a bold and talented leader, and received great honours in the new American republics. He returned then to his own country, and devised new methods of shipping and mining, and decided that no women or children should be forced to work underground in the coal mines of his family.

As time passed, other judges looked once more at the Commander's trial and then ruled that it had been unfair. The Commander's rank and honour were restored and indeed he rose to be an Admiral in the British Navy. When he died, he was buried in the great abbey in the capital city where his banner had 
once been abused, and his family was awarded a large sum in recompense for the injury suffered by the Commander.

Cochrane's story is mainly an illustration of the manipulation of the legal process for political purposes in the early nineteenth century. Yet the sanctions imposed, although frustrated in a notable example of popular justice, were extreme, especially in their accumulation, especially in relation to a fledgling offence, a situation which would now be officially castigated as market manipulation. Although historically separated, it is instructive to compare Cochrane's case with the recent case of Ian Hannam, mentioned below.

\section{Bernard Huddlestone (Mid-Nineteenth Century, Fictional)}

Huddlestone is a central character in the short story (or novella) by Robert Louis Stevenson, The Pavilion on the Links published in $1880^{24}$ but dealing with events some 50 or so years earlier and set in a remote location on the Scottish coast. Huddlestone's role in the narrative is a credible enough account of corruption in the nineteenth-century banking system. Quite simply, the man in his role of banker embezzled money belonging to an Italian 'secret society' violently committed to the cause of Italian unification and independence (the 'Risorgimento'), evidently part of the Carbonari network.

Huddlestone's part in the story is mainly as a trigger and as context, but his own character as cowardly and dishonest is used as a foil to that of his daughter, more noble and morally upright, who is sought in rivalry by the two other protagonists, Cassilis and Northmoor. Despite the attempts of the latter two to protect and secure the escape of the fugitive banker, the Italian society attack the remote pavilion before Northmoor's boat can carry them away. The building set on fire, Huddlestone is shot down in the doorway to a jubilant cry of 'traditore'. It is also, therefore, a tale of informal justice, previewing in some respects the twentieth-century actual biography of Roberto Calvi (see below).

Stevenson's presentation of Huddlestone's character is plausible. He had been a highly successful banker whose business had later failed, then bringing distress to a number of his clients and tempting him into the embezzlement of the Carbonari money deposited in his bank, and so frustrating plans for revolution in Italy. Huddlestone had become a fugitive from different kinds of justice and retribution, but his physically prostrating fear of savage Carbonari reprisal far outweighed his apprehension of formal criminal justice. And so he sought a safe haven on a Pacific island (like Fletcher Christian and the mutineers on

24 Robert Louis Stevenson, The Pavilion on the Links (first published in 1880, recent edition by Demetra Publishing, 2019). 
The Bounty) rather than surrender to British criminal justice. Stevenson depicts Huddlestone in the following passage.

I was astonished at the wit and information he displayed. Mr Huddlestone's was certainly no ordinary character; he had read and observed for himself; his gifts were sound; and, although I could never have learned to love the man, I began to understand his success in business, and the great respect in which he had been held before his failure. He had, above all, the talent of society; and although I never heard him speak but on this one and most unfavourable occasion, I set him down among the most brilliant conversationalists I ever met.

He was relating with great gusto, and seemingly no feeling of shame, the manoeuvres of a scoundrelly commission merchant whom he had known and studied in his youth, and we were all listening with an odd mixture of mirth and embarrassment when our little party was brought abruptly to an end in the most startling manner. ${ }^{25}$

This presentation of Huddlestone's crime and character is straightforward but convincing and typical.

\section{Aron Salomon (Late Nineteenth Century)}

In the later years of the nineteenth century Aron Salomon established a wholesale bootmaking business in London, which for some time was a thriving enterprise. The business was supported by the participation of his sons who in due course agitated for some real share in the profits of the business, to be partners rather than servants. Aron's response in due course was legally very nifty $^{26}$ as a means of securing his own continuing control and financial position. A company was formed in his name, providing a few shares to members of his family, but with Aron as the majority shareholder and eventually as a privileged creditor. In one sense the company was a legally distinct person, but in economic terms little more than the alter ego of Aron the individual entrepreneur. This arrangement worked to Aron's advantage when the business later began to fail (hit badly by economic downturn and labour disputes in the bootmaking business, leading to a fall in profits and rise in debts), and when the business collapsed Aron was able to claim against the company ahead of its other creditors. This outcome prompted a legal challenge of the arrangement, alleging on the one hand some fraud on Aron's part, but also a fundamental attack on the rules of corporate law which could allow such a clever evasion of liability and indeed profit on the part of the business's founder.

\footnotetext{
25 Ibid., pp 63-4.

26 For a detailed account, see the report of the House of Lords case, Aron Salomon v A. Salomon and Company (1897) AC 22.
} 
The judges held ${ }^{27}$ that there was factually in the case nothing to support an argument of fraudulent behaviour and also, in a seminal judgment of the House of Lords, that rules of company law could be properly used to achieve the outcome in Aron's favour. ${ }^{28}$ This view favourable to Aron the man is articulated most clearly in the judgment of Lord Macnaghten, who could not 'help thinking that the appellant, Aron Salomon, has been dealt with somewhat hardly in this case', and that the company had fallen upon evil days - in the end, 'Mr Salomon availed himself to the full advantages offered by the Act of 1862 , and what is there wrong in that?'29

This final judicial view was that Aron Salomon was not a fraudster but rather a victim of the vicissitudes of business, availing himself of what the law might offer. If this was bad business then it was legally sanctioned and the debate has continued regarding the good or bad consequences of the company with limited liability, one more recent argument being that it has proven a recipe for corporate irresponsibility. ${ }^{30}$

\section{William Lever, Ernest Hyslop Bell and Walter Edward Snelling (Early Twentieth Century)}

In a historical perspective the late nineteenth and early twentieth centuries may be regarded as an era of pioneering entrepreneur-philanthropists whose careers have provoked reactions of ethical ambiguity - business giants such as John D Rockefeller, Andrew Carnegie and John Pierpoint Morgan, leading examples from the 'Gilded Age' in the United States. A comparable British contemporary was William Lever. Something of the latter's career has been summarised in the following way.

William Lever (later Lord Leverhulme) was another example of a self-made leading entrepreneur and tycoon of the time, rising from modest grocer to soap manufacturer and monopolist via the foundation of Lever Brothers, a major international corporation which was the forerunner of the present-day Unilever company. ${ }^{31}$ Lever

27 To be exact there was judicial disagreement within the appellate process, and the Court of Appeal ruled against Aron the man, opining that 'Mr Salomon's scheme is a device to defraud creditors': see Broderip v Salomon (1895) 2 Ch 323, 339 per Lindley L J. The judges in the House of Lords then viewed the matter differently, an interesting legal story in itself.

28 See (1897) AC 22 (n 26).

29 Ibid., pp 47ff.

30 Paddy Ireland, 'Limited Liability, Shareholder Rights and the Problem of Corporate Irresponsibility’, 34 (2010) Cambridge Journal of Economics 837.

${ }_{31}$ See Charles Wilson, The History of Unilever (Cassell, 1954), vol 1. For detailed biography, see Adam Macqueen, The King of Sunlight: How William Lever Cleaned up 
Brothers had expanded since its foundation in 1890 and by the early years of the twentieth century Lever was pursuing a policy of amalgamation with competing soap manufacturers and in 1906 wished to emulate the American trust method. The so-called Soap Trust was however subject to a fierce campaign of vilification in the popular press, especially in the Daily Mail and Daily Mirror, controlled by Alfred Harmsworth (later Lord Northcliffe), as the 'Greedy Soap Trust'. Part of the attack was the accusation that the Soap Trust was cheating consumers, charging higher prices for less soap. The campaign succeeded in damaging soap sales and the trust was abandoned. ${ }^{32}$ Subsequently Lever was able to claim libel damages from the Harmsworth newspapers - a record sum of $£ 91,000$, some of which was used to endow departments of Liverpool University. ${ }^{33}$

On the one hand a monopolist and price fixer but also a benefactor of employees (establishing a model village for workers at Port Sunlight) and of culture and education, Lever's career invites complex assessment 100 years later. But there is an interesting further episode in the later history of Lever Brothers, as the company in the 1920s turned its gaze to the lands of Western Africa and the plentiful supply of cocoa beans there, as a source of oil for the making of fine quality soap.

However, initially the trade with the suppliers of the cocoa beans did not prosper. By this time Lever was entrusting more of the management of business to others, especially D'Arcy Cooper, a skilled accountant who was also a Quaker. In relation to the West African enterprise, D'Arcy Cooper in turn sought out the service of two 'rainmakers' as such people might now be termed businessmen with a proven ability to turn the unprofitable into the profitable, Ernest Hyslop Bell and Walter Edward Snelling. Under their direction, the trade in cocoa beans was thriving within a few years. Lever and D'Arcy Cooper were encouraged to extend the trading empire in cocoa and oil by amalgamating with rival firms. In this new venture, they decided to dispense with the services of Bell and Snelling, but agreed a handsome payoff for the latter, with which they were well satisfied.

D'Arcy Cooper subsequently discovered that the rainmakers had at the same time privately traded in West Africa for their own profit, having involved the company in a cocoa cartel or 'pool' and used their inside knowledge of the cartel's pricing strategies to further their own business - in effect engaging in what would a century later be regarded as anti-competitive price-fixing

the World (Random House, 2005); Brian Lewis, 'So Clean': Lord Leverhulme, Soap and Civilization (Manchester University Press, 2008).

32 For a detailed account, see Wilson (n 31), pp 72-88 ('The Crisis of 1906').

33 Christopher Harding, 'Popular Justice and the Regulation of Trade: Muckraking, Rough Music, Political Cartoons and the Vilification of Entrepreneurial Heroes' 12 (2018) Law and Humanities 204, pp 220-21. 
offences and insider trading. But D'Arcy Cooper was dismayed at the furtive breach of trust, as he viewed the profiteering, and then sought to recover the payments made by the company to Bell and Snelling. That would have been a serious personal blow to both and the move led to a strenuous legal battle, ${ }^{34}$ culminating in the House of Lords' judgment in Bell v Lever Brothers, ${ }^{35}$ which is mainly remembered as a seminal ruling on the effect of mistake in the English law of contract. Lever Brothers lost the case, since the mistaken belief of the company in Bell and Snelling's bona fides was held to be insufficient to render the settlement legally void.

Altogether, this is a tale of business practice, which may not have been clearly illegal at the time but would be viewed differently in an early twenty-first century legal context, but which may in any case lead to an uncertain and ambiguous moral evaluation of the conduct of all the parties. There is further more detailed discussion of the background to Bell v Lever Brothers in Chapter 3.

\section{Robert Maxwell (1923-91)}

Maxwell may be best described as a high-profile entrepreneur, whose career comprised being something of a war hero (Second World War), the building of a business empire, and some time as an elected politician, media proprietor and household name. Born in Ukraine, Britain became his country of adoption and the base for his business activity in publishing (the Pergamon Press) and in the popular press (owner of the influential tabloid newspaper the Daily Mirror). He was for a period an elected Westminster MP (Labour Party) and maintained a high-public profile. At the end of the 1960s he was the subject of a Department of Trade and Industry (DTI) investigation which reported critically on his 'lying, exaggerating, distorting, concealing and general company law-breaking' and 'creative accounting', although he was not subject to any criminal prosecution. Despite the reputational damage, Maxwell bounced back in entrepreneurial terms, developing a network of private companies and control of a public enterprise, Mirror Group Newspapers. Confronting a huge debt crisis by the start of the 1990s, Maxwell carried out a looting operation on his own companies, and in particular the fraudulent raiding of the Mirror Group Pension Fund. Late in 1991 he fell over the side of his luxury yacht in the mid-Atlantic Ocean, in what may have been an act of suicide.

34 For a detailed critical account of the litigation and its background, see Catharine MacMillan, 'Trial: How Procedure Shapes Substance', 19 (2008) King's Law Journal 465.

35 Bell v Lever Brothers (1932) AC 161. 
Punch provides a convenient summary of Maxwell's career and business activity and analysis of his character and methods as a business actor. ${ }^{36}$ In constructing a profile of business delinquency, there is evidence of a brash, and apparently winning and seductive, boldness and determination, though not necessarily great business acumen, coupled with a more private and interpersonal ruthlessness and resort to bullying. In Punch's summary, Maxwell was a very good and highly successful confidence trickster:

he created a near impenetrable web of companies and holdings fully utilizing the opportunities by 'off-shore' and other tax havens protected by secrecy ... Almost all that he did was cloaked in legality and sealed with the approval of lawyers, accountants and bankers. He was only exposed as a fraud on a grand scale after his death ... the regulators simply failed to nail him down and the financial establishment of the City of London continued to support him right up to the end. ${ }^{37}$

This analysis suggests a character of dishonesty and deception, based on a cleverness of exploitation and persuasive collusion. But such were the flaws of character and certain areas of weakness, his delinquent project was doubtfully sustainable, and likely to crash at some point, as indeed happened. But it is interesting to note that this entrepreneurial edifice tumbled down as a result of its inherent weakness rather than as the result of any legal enforcement.

\section{Ernest Saunders (b.1935)}

Like Maxwell, Ernest Saunders was born in the middle of the twentieth century in central Europe, in Austria, but his Jewish family moved to Britain shortly after, fleeing Nazi persecution. Saunders was educated at Cambridge University and went on to have a very successful business career, being viewed by the early 1980s as a 'white knight' rescuer and developer of large enterprises. Having made his reputation as an astute and dynamic business manager with Nestlé, he turned matters around for the moribund and ramshackle Guinness company which he then led into the high-profile takeover of other major drinks companies, Arthur Bell, and then Distillers. These takeovers were more predatory than first projected, and by 1986 Saunders and some other managers were facing criminal charges in relation to illegal share support and other offences involving manipulation, dishonesty, conspiracy and false accounting. His subsequent trial and conviction was a kind of showcase for taking strong legal action against a new aggressive corruption in the marketplace, 'greed in the saddle', and the sentencing judge castigated Saunders for his promotion

36 Punch (n 20), at pp 5-9.

37 Ibid., p 7. 
of an unacceptable business ethos ('a casino economy'). Saunders was able to launch a counter-attack against his five-year prison sentence - his lawyers exploited evidence of Alzheimer's disease to reduce the time actually spent in prison to just ten months, and proceedings before the European Court of Human Rights exposed the illegality of some of the evidence used against him for violation of the principle against self-incrimination. Eventually his career revived to the extent of gaining lucrative consultancy work. This then, was a more nuanced and ambiguous kind of delinquency compared with Maxwell's career, and it may be said that the battleground was more one of ethics than manifest criminality. Undoubtedly astute and clever, there were moral flaws in Saunders's character, being mendacious and obsessive. But he achieved some rehabilitation in the court of wider perception, one comment in 1996 stating:

he is succeeding in re-writing history. His offences, the organisation of a secret share-support operation of unparalleled scale and the payment of $£ 25$ million to his co-conspirators, are now seen by some as little more than a series of largely technical breaches of City rules. Many think him unfairly treated..$^{38}$

Saunders has also been described as an outsider, ${ }^{39}$ something to bear in mind in seeking some understanding of the motivation and character of such high-flying delinquent entrepreneurs.

\section{Roberto Calvi (1920-82)}

Perhaps what is most distinctive about the example of Roberto Calvi ${ }^{40}$ as a delinquent business person is the Italian context of his career and activities, such as to supply elements of both drama and complexity to the narrative (and inspire a fictional recreation in Coppola's Godfather III film ${ }^{41}$ ). Calvi rose to be the head of a leading Italian bank, Banco Ambrosiano, the activities of which interrelated with the Vatican polity, other leading delinquent bankers and organised crime from the 1970s through to the start of the 1980s. In financial and legal terms, Calvi's eventual control of this powerful bank enabled a series of illicit financial manoeuvres based on complex deception, breaches of criminal law and financial regulations, manipulation of the stock exchange and, incidentally, the creation of opaque channels for illegal transactions associated

38 Jeremy Warner, 'Profile: Ernest Saunders; Out of Jail and Back in Business', The Independent, 18 May 1996.

39 Ibid.

40 Again for a convenient summary of Calvi's career and analysis the criminal complexity, see Punch (n 20), pp 180-98. For a detailed biographical account, see Larry Gurwin, The Calvi Affair: Death of a Banker (Macmillan, 1984).

${ }_{41}$ The Godfather Part III (dir. Francis Ford Coppola, 1990). 
with arms and drug trafficking, terrorist activity and bribery and corruption. It was a long and complex narrative of 'smokescreen' and involved a cast of different actors spanning the financial, political and organised crime spheres. Increasing regulatory suspicions from the later 1970s led to a 'closing in' on Calvi and Banco Ambrosiano, culminating in criminal charges and conviction in 1980 and 1981, the failure of the bank, and finally Calvi's flight to London and death there in mysterious circumstances - his body was found hanging from the scaffolding under Blackfriars Bridge. The history and machinations of Banco Ambrosiano served as a template for what is now the standard fare of a popular genre of fiction, drama and cinema depicting high-level financial crime set in a web of international complexity. ${ }^{42}$

Commentators such as Punch ${ }^{43}$ have stressed the Italian connection in this example of business bad behaviour - political elements (the Vatican), organised crime and Italian culture - but it is also possible to identify other wider and recurring themes. Again this is in some respects an account of regulatory laxity and difficulty in dealing promptly and decisively with an admittedly complex and well-concealed network of actions and transactions. And there are also some interesting observations regarding Calvi himself, as an important individual protagonist, in so far as he is presented as an outsider with certain feelings of insecurity, which may have motivated a need for personal control of a large organisation and the resort to secretive and deceptive practice in conducting business, resulting in a kind of double life. In his biographical account, Gurwin comments:

Calvi's fatal flaw was that he had a dual character or, as Mazzola put it, 'two brains' ... 'Brain number one is good. It's the brain that has built Banco Ambrosiano into a big, solid, prosperous, well-run bank. Brain number two thinks that the world is run by conspiracies. ${ }^{44}$

Such perceptions of character and psychological make-up are instructive, in presenting an analysis of personality where cleverness and skill interact with insecurity to motivate delinquent conduct. ${ }^{45}$ The application of psychological

42 There is now a large body of fictional representation, much of it well researched and convincing and which serves to educate audiences and readership regarding the causal and evidential complexity of business crime and delinquency, ranging from the cinematic presentation in Coppola's Godfather III film (ibid.) to the 2016 Scandinavian TV drama Follow the Money (Danish: Bedrag). Such representations should now be taken seriously in sociological terms as part of the subject itself.

43 Punch (n 20).

44 Gurwin (n 40), p 199, quoting the defence lawyer Valerio Mazzola.

45 See also Manfred F R Kets de Vries, 'Leaders on the Couch: The Case of Roberto Calvi', INSEAD (France) 90/40/08 (1990). 
theory and insight to a biographical narrative, especially when combined with some appreciation of cultural context, may aid in both an understanding of individual motivation and action and also in an unravelling of individualorganisational interactions and eventually any allocation of responsibility. Such an approach may transform the perception of Calvi as a criminal mastermind to something weaker, a victim of both individual psychology and external culture. ${ }^{46}$

\section{Nick Leeson (b.1967)}

The career of Nick Leeson and the collapse of the well-established merchant bank, Barings, in the mid-1990 $\mathrm{s}^{47}$ now stands as a celebrated case and, many would argue, an object lesson in financial mismanagement. In some respects this example derives (in contrast to some other examples) from a relatively simple narrative. Leeson joined Barings in 1992 as a derivatives trader. He was appointed the general manager of an operation in futures markets on the Singapore International Monetary Exchange (SIMEX). In that speculative trading role he was for a while hugely successful, earning very large profits for the Bank and bonus payments for himself. This may have been a matter of gambler's fortune and his own considerable self-belief, but in early 1995 the profit was rapidly transformed into much bigger losses, triggered by the earthquake in Kobe in Japan. Leeson's final rash gambling made the losses worse, amounting to more than the Bank's reserves, and the Bank was suddenly bankrupt by the end of February 1995, and beyond any attempts at rescue. Leeson fled the jurisdiction, and was later extradited from Germany back to Singapore, to face a trial and conviction for unauthorised dealings. In fact, the Bank had given Leeson a good deal of autonomy in relation to his successful dealing, but he had acted without authority and sufficiently so to justify charges of fraud and forgery. He was sentenced to a term of six-and-half-years' imprisonment in Singapore, but was released in 1999. Both in the media and in cinema he was presented as the classic 'rogue trader'. ${ }^{48}$

Although Leeson appeared as a brash, overconfident and reckless gambler who in some ways both seduced and duped his employer, both SIMEX and the Bank of England were very critical of Barings's role in the matter, and

46 Ibid.

47 Full a fuller account, see Punch (n 20), pp 31-8. See also Leeson's autobiographical account, Rogue Trader (Little, Brown, 1996), and his later autobiographical work (with Ivan Tyrrell), Back from the Brink: Coping with Stress (Virgin, 2005). For a cinematic version, see Rogue Trader (dir. James Dearden, 1999).

48 This term is widely used to describe the maker of unauthorised transactions, especially in financial markets. 
castigated the Bank for its failure in supervision. ${ }^{49}$ Initially Barings attempted to scapegoat Leeson and others by suggesting that it had been the victim of a criminal conspiracy and a planned attempt to wreck the Bank, but there is no evidence beyond that which shows Leeson to be a solo rogue trader acting in a complacent and sloppy environment of corporate governance. The disastrous outcome appears to be due to a combination of individual arrogance and corporate inattention, and both could be said to be on the scale of recklessness. Three points may be noted from this example for purposes of further discussion. First, there is the issue of allocating responsibility between a corporate institution and an individual employee. Second, there is the assessment of delinquency in a context of business activity viewed as a kind of gambling, and an individual employee carrying out his role in a way very much expected of him. Is the objectionable activity in that sense natural to the business world and the particular role of the delinquent actor? Third, there is the question of the individual perpetrator's own character and motivation. Interestingly, like Maxwell and Saunders, Leeson is also presented as an outsider, ${ }^{50}$ although in this instance, lower class and from Watford, in the context of aristocratic merchant bankers.

\section{Bank of Credit and Commerce International (BCCI) (1972-91)}

BCCI was a vast international banking organisation, the narrative history of which is factually and legally complex and whose activities over a period of some 20 years comprised a range of serious crimes and wider criminal connection. In the words of New York District Attorney, Robert Morgenthau, the Bank's activities comprised:

the largest bank fraud in world history. BCCI was operated as a corrupt and criminal organization throughout its entire nineteen year history. It systematically falsified its records. It knowingly allowed itself to be used to launder the illegal income of drug sellers and other criminals. And it paid bribes and kickbacks to public officials. ${ }^{51}$

It is worth reflecting on this quoted description of the Bank's criminal role. Morgenthau's statement of cause served a rhetorical purpose within the legal process. The totality of the condemnation there presents the Bank as something founded determinedly as a sophisticated and powerful crime organisation and

49 Board of Banking Supervision, Report into the Collapse of Barings Bank, July 1995, HC 673, 1994-95.

50 Punch (n 20), pp 32-3.

51 Referring to the criminal indictment of the Bank in the US, 29 July 1991. Again, for a convenient summary of the BCCI as a case history, see Punch (n 20), at pp 9-15. 
operated by all involved consciously as such. But, as Punch concedes, it may have been a matter of deviousness and mismanagement leading to criminal solutions..$^{52}$ There was undoubtedly a range of significant and large-scale 'criminal solutions' and strategies tied together in a single organisation, but the easy confidence of Morgenthau's presentation does mask some complexity of delinquent agency, regarding the role of individual and collective elements, and that goes to an assessment of the nature of the delinquency. In many respects this narrative provides a classic study of the intersection and interrelation of business criminality and corruption - fraud and false accounting, laundering, bribery. But the framework for understanding all of this, whether as an organisational structure or something of significant independent corporate agency - is less certain. Is the BCCI story one of an organisation or one of individual human actors? It is less obviously the latter and is often presented under the heading 'BCCI'. Yet there were a number of leading human players and their role should still be considered. For instance, the bank was founded by Agha Hasan Abedi (1922-95), who retained a leading role until suffering a heart attack in 1990. Abedi was described as a charismatic figure in the Pakistani business community, and was also a Muslim mystic, and a philanthropist. Eventually indicted for BCCI-related criminal offences in a number of jurisdictions, Pakistan would not countenance his extradition. How does such an individual fit into the overall scheme of responsibility? This uncertainty is compounded by a second narrative (once more) of supervisory failure and hesitation on the part of regulators and legal systems. And, third, victimhood and the risk to others, complicates an overall assessment - the 'thousands of employees, investors, pensioners and businessmen who had lost their money' in the unravelling and eventual legal sanctioning of the Bank..$^{53}$ The criminal prosecution and sanctioning of certain individuals was a self-evidently appropriate response, but it is only part of the story, particularly if that story involves a greater longitude of causes and outcomes.

\section{Arthur Andersen (est. 1913)}

Arthur Andersen was a major American public accounting firm whose fall from grace represented a dramatic transformation from a highly respected to delinquent organisation. ${ }^{54}$ The firm was established in 1913 by Arthur E Andersen, then a young professor of accounting with a strong reputation

\footnotetext{
Ibid., p 10.

Ibid., p 14.

54 For a convenient summary of the firm's history, see the entry: 'Arthur Andersen', Encyclopaedia Britannica, 2019.
} 
for integrity. By the late twentieth century the firm had grown into a major international player specialising in high-quality auditing. However, from the 1970s there was a general shift in professional accounting services to embrace high-earning consultancy as well as traditional auditing. Consultancy became more lucrative, leading the firm to sell an increasing range of consultancy services and also a dependency on client satisfaction. This represented a professional culture shift, and most relevantly a change of attitude, with an emphasis on providing what the client wanted to hear in the outcome of auditing. On the one hand there was a more cynical market-led exploitation of clients over-billing and providing a less-qualified service. On the other hand, there was a need to keep the client happy, and that eventually resulted in collusion in fraud and also succumbing to pressure from some large corporate clients in relation to how auditing was carried out.

By the turn of the century the US Securities and Exchange Commission (SEC) had started to investigate some of these activities. In 2001 the SEC issued a cease-and-desist order against Andersen following regulatory violations relating to a huge accounting fraud at Waste International, a major client. At about the same time, concern was developing within both Arthur Andersen and the Enron Corporation about an imminent SEC investigation, prompting the former to start a programme of document destruction. While this was underway the SEC subpoenaed Andersen for Enron-related material. The Andersen partner in charge of the Enron account, David Duncan, was dismissed from the firm and official suspicions were voiced relating to other companies for whom Andersen had issued unqualified or clean audits, companies who were under investigation, restating previous financial statements or suddenly declaring bankruptcy. In 2002 the US Department of Justice indicted the firm for obstruction of justice.

The outcome for the firm was catastrophic. It was deserted by many of its clients, then later that year was found guilty of obstructing justice and lost its licence to engage in public accounting. David Duncan, charged with the same offence, pleaded guilty. The conviction of both was later overturned by the Supreme Court on the ground of faulty jury instructions, and Duncan thus avoided a prison term. ${ }^{55}$ But the company had shrunk to a handful of people managing legal claims. 2005.

55 'Enron Auditor Withdraws Guilty Plea', Accounting and Tax, 23 November 


\section{Tom Hayes (b.1980)}

Like Neeson, Hayes was a trader and again in that role the narrative of delinquency is relatively straightforward as one of largely individual action involving market manipulation. It is rather as an example of criminal justice that Hayes's case is more distinctive, and then raising some issues worthy of further reflection. Hayes provides another example of a kind of rags-to-riches trajectory in his career - from a relatively modest background and early career position, but highly numerate and single-minded, and in fact later diagnosed as suffering from Asperger's syndrome. There is evidence of a somewhat amoral mind set, in his admission of dishonesty but refusal to regard his own actions as morally deficient. The nature of his offending and its evaluation for sentencing purposes are well summarised in the remarks of the trial judge, Cooke J, in passing sentence:

The evidence established that when you arrived at UBS, some internal manipulation was going on, mostly in other currencies, of which you were essentially unaware but not external manipulation of Yen LIBOR of the kind which you engendered. It was you who developed the practice among the yen traders and submitters and had all the contacts with the London brokers and one or two traders or traders/submitters at other banks who would do as you asked if you would do the same for them, as you offered to do ... You played a leading role in the manipulation of Yen LIBOR as was recognised by others at the time. You exerted pressure on others, effectively training those junior to you in the activities in which you were involved. You made corrupt payments to brokers for their assistance..$^{56}$

This presents Hayes in a ringleader role, developing and facilitating the process of market manipulation. 'Manipulation' is an apposite term in the case of this individual, and in effect describes his subsequent role in the legal process, first providing evidence in order to avoid extradition to the USA, then opting out of the 'SOCPA' (evidence assistance and immunity) process ${ }^{57}$ after his advantage had been gained:

You made use of the SOPCA process, agreeing to plead guilty and give evidence against co-conspirators before opting out of it, when the threat of extradition had diminished. Thereafter, every legal argument that could be made has been made. I make it clear that I do not increase the sentence on that account, but it means that

56 Sentencing remarks of Mr Justice Cooke, $R v$ Tom Hayes, Southwark Crown Court, 3 August 2015, paras 9-10.

57 SOPCA, for Serious Organised Crime and Police Act 2005, ss 71ff, providing for SOCPA 'agreements'. 
there is little to be said in mitigation even if some information supplied may assist the prosecuting authorities in pursuit of some lines of enquiry. ${ }^{58}$

As a rogue trader, the narrative of Hayes's career may appear unexceptional, but as a narrative of legal response there are points of interest. Compared to Leeson's prison term, Hayes's original sentence of 14 years may appear severe, ${ }^{59}$ and indeed this provided one motivation for his subsequent saga of legal claims. There is some sense in which he served as a convenient 'poster child' 60 at a time when official rhetoric of condemnation and formal legal action was moving into a higher gear in relation to market manipulation; ${ }^{61}$ and the sentencing judge was explicit about the deterrent message which was intended in the prison sentence. ${ }^{62}$ Subsequently, Hayes appealed against his conviction for conspiracy to defraud (raising questions about the nature of this criminality), unsuccessfully although gaining some reduction in the prison term; ${ }^{63}$ then, unsuccessfully, against the confiscation of his assets (raising questions about the accumulation of sanctions); ${ }^{64}$ and then having his case referred to the Criminal Cases Review Commission (raising questions about the nature of the evidence). ${ }^{65}$ From a legal point of view, this is a rich case, which prompts reflection about the collection and sufficiency of evidence, the choice of sanctions, and the characterisation of this kind of business conduct as criminal or otherwise illegal. This provides us with an important theme of argument - how to understand and evaluate 'trader chicanery' as a product of the actions of a 'socially awkward math genius', of 'a handful of outrageous confederates', and the result of a 'deeply corrupt banking system'- whose responsibility for what? ${ }^{66}$

58 Sentencing remarks (n 56), at paras 4-5.

59 Also compare the case of Jerome Kerviel in France: 'Court Slashes Damages Owed by Former SocGen trader Jerome Kerviel', The Guardian 23 September 2016.

60 In the derogatory sense of archetypical bad behaviour.

${ }^{61}$ For instance, EU measures exhorting the use of effective legal enforcement. See the discussion by Sarah Wilson and Gary Wilson in Vanessa Franssen and Christopher Harding (eds), in Criminal and Quasi-Criminal Enforcement Mechanisms in Europe (Hart, 2021).

62 'The conduct involved here must be marked out as dishonest and wrong and a message sent to the world of banking accordingly' (Sentencing remarks (n 56), at para 12; emphasis added).

63 (2018) 1 Cr App Rep 10.

64 (2018) 2 Cr App Rep (S) 27.

65 Ongoing in 2021. But Hayes was released from prison on licence in January 2021 after serving five-and-a-half years of his sentence.

66 See the account presented by David Enrich, in The Spider Network: The Wild Story of a Math Genius, a Gang of Backstabbing Bankers, and One of the Greatest 


\section{Alfred Taubman (1924-2015)}

The business and legal context of Taubman's criminality - antitrust collusion contrary to the US Sherman Act of 1890 - is somewhat different. ${ }^{67}$ Although long regarded as a serious crime under US law, anti-competitive collusion is dealt with variably across jurisdictions and there is still some resistance (for instance in some continental European countries) to criminalising such conduct, whether on the part of individuals or companies. ${ }^{68} \mathrm{~A}$ major part of the harm considered to result from such activities as price-fixing and market sharing is usually a dispersed economic injury inflicted on a large number of consumers. The American condemnation is based on an idea of damaging conspiracy, while other jurisdictions have struggled to find an analogy between such business collusion and theft or fraud. Nonetheless, successful, almost iconic business entrepreneur Alfred Taubman fell foul of a high-profile prosecution for his role in the Christie's-Sotheby's art-house auctions cartel and served a one-year prison term. Nor was this a typical business cartel arrangement, but was something of an executive frolic at the highest level, since the conspiracy was confined to two company chairmen and two CEOs. ${ }^{69}$

The collusion - regarded with alarm by the two companies as such and their in-house lawyers, when revealed - was reported by Christie's, who thereby gained immunity from prosecution. The brunt of the legal proceeding was then borne by Taubman, as chairman, and Diana Brookes, as CEO of Sotheby's. Brookes pleaded guilty and provided evidence in order to gain leniency in sentencing (successfully), thereby implicating Taubman as a commanding mastermind of the commission-fixing arrangement. Taubman haughtily pleaded his innocence and refused to testify, but was convicted alongside Brookes; however, she avoided a prison term. He steadfastly maintained that he had been set up by Brookes and the Department of Justice, and was staunchly unrepentant thereafter.

Scams in Financial History (Custom House, 2017). The Hayes legal saga is doubtless not yet over.

67 For a more detailed account of Taubman's career and involvement in the art house auctions cartel, see Arthur Austin, 'A Price-Fixer's Memoir - Exculpation and Revenge While Confronting the Antitrust Abyss: An Essay on Threshold Resistance by Alfred Taubman', Antitrust Source, October 2008; Christopher Mason, The Art of the Steal: Inside the Sotheby's-Christie's Auction House Scandal (Putnam, 2004).

68 See Christopher Harding and Julian Joshua, Regulating Cartels in Europe (2nd edn, Oxford University Press, 2010), pp $342 \mathrm{ff}$.

69 For a detailed account and analysis of the cartel and its prosecution, see Harding and Edwards (n 19), at pp 167ff; Orley Ashenfelter and Kathryn Graddy, 'Anatomy of the Rise and Fall of a Price-Fixing Conspiracy: Auctions at Sotheby's and Christie's', 1 (2005) Journal of Competition Law and Economics 3. 
In personality and career, Taubman provides a classic example of rags-to-riches success, and of entrepreneurial skill in making a huge fortune, largely by developing and promoting the concept of the shopping mall. In broader historical terms he was a contemporary of Maxwell, Saunders and Calvi. He was the son of immigrants to the USA from Eastern Europe, and his parents fared badly in the Depression era. From that background in Pontiac, Michigan, Taubman rose to become one of the wealthiest businessmen in the country, and in the 1980s as a 'white knight' purchased and rescued the ailing auction house, Sotheby's. In that regard, he engendered a suspicion on the part of the metropolitan elite. As he later wrote in his autobiographical defence: 'I was accused of turning Sotheby's into Bloomingdale's'. On one view, his conviction depended on the trial jury's assessment of the conflicting evidence from himself and Brookes, and the predominantly 'blue-collar' jury did not warm to Taubman during the trial. ${ }^{70}$ After serving his sentence, he published an exculpatory autobiography, ${ }^{71}$ and his reputation overall and in the long term did not appear to suffer: he is mainly remembered for his innovative and successful business methods, his art collection and his philanthropy. The outcome of most internet searches comprises biographical sketches which downplay or omit completely his encounter with the Sherman Act.

Taubman is included in this list because he was a significant business actor convicted of a serious criminal offence perpetrated in the course of business. But in many respects he does not match the other delinquent actors in the list, in that he does not appear as a serial business offender but as a successful entrepreneur engaging in a criminal frolic. But as such, his case serves as a useful benchmark of delinquency and criminality to be taken into account in an analysis of bad business behaviour. As an example, it raises important questions regarding the legal and ethical aspects of illegality and criminality, the sufficiency and character of evidence, and the choice and operation of legal sanctions.

\section{Ian Hannam (b.1956) $)^{72}$}

Ian Hannam was born and grew up near Bermondsey in South London, had aspirations to be an army officer but failed selection for training at Sandhurst, and instead graduated in engineering at Imperial College London and joined the Special Air Service (SAS), an elite British army unit, in a part-time role,

\footnotetext{
70 Austin (n 67).

71 A Alfred Taubman, Threshold Resistance: The Extraordinary Career of a Luxury Retailing Pioneer (HarperCollins, 2007).

72 For a fuller account and critical discussion of the Hannam case, and also further sources, see Chapter 4 in this volume, in relation to market manipulation or abuse.
} 
where he rose to the rank of captain. In civilian life he worked for the construction company Taylor Woodrow, and then as an investment banker, with Salomon Brothers, Robert Fleming, and then JPMorgan. At JPMorgan he rose to the level of chairman of global capital markets. In banking, Hannam's career was undoubtedly successful, exploiting a style and approach described as 'buccaneering'. But this career fell apart after the revelation of a regulatory breach.

In 2012 the UK Financial Services Authority (FSA) fined Hannam for disclosing inside information in relation to a small oil company in two email messages, suggesting that the company had recently discovered a new source of oil, and that it was about to be taken over. In the event, nobody traded on the information, but the FSA argued that there was the potential for somebody to profit from the disclosure, and that was sufficient to constitute a regulatory code of conduct breach. He was fined $£ 450,000$ and he resigned his position with JPMorgan in order to clear his name. The FSA said (in double negative language) that Hannam 'did not act without honesty and integrity', but as a senior role model needed to be subject to a deterrent measure against committing market abuse. This did not mean an end to Hannam's career and business, but effectively condemned him to working in a lower league of trading.

Hannam's conduct was not cast as criminal, in formal legal terms. He had his defenders within the business community and in the political arena, and even a certain degree of ethical exoneration from regulators. The case involved a clear admission of exemplary treatment and illustrates the personal and actual impact of sanctions outside the sphere of criminal law. This may be understood perhaps as not so much an evaluation as clever or bad, but as a policy-driven reaction to a buccaneering style of business. ${ }^{73}$

\section{IMPORTANT LINES OF ANALYSIS}

These biographical sketches are designed to provide a fuller sense of the context, motivations, personal history and character of protagonists, and systemic forces which contribute to historical incidents of business delinquency, as a kind of criminological profiling. Some reflection on such case studies prompts further discussion along certain main lines of analysis, as a way of elucidating the subject.

Four such main analytical themes emerge.

73 See also the discussion by Wilson and Wilson (n 61). 


\section{Legal Categorisation}

There is a real dilemma of legal description, of how to describe, define and categorise such activities for legal discussion, purposes of legal control, and in particular regarding any use of criminal law. It is possible first of all to employ familiar and well-established but quite wide legal descriptions, in particular: fraud and deception; theft; bribery; counterfeiting; and conspiracy. But then, and more recently there have been attempts at more specific offence definitions, such as money laundering, insider trading, market manipulation and cartel offending. But the conceptual clarity and practical feasibility of these terms remains problematical.

\section{Individual Characteristics and Circumstances}

How should the individual business actors be understood in this context of bad behaviour in the marketplace? There are some commonly found characteristics and circumstances which emerge from empirical observation:

entrepreneurship, a gift for innovation, business acumen and charisma; a gambling and risk-taking temperament;

a 'rags-to-riches' career trajectory;

personal character as a 'social outsider';

a trickster and chameleon personality.

To some extent these characteristics may overlap and interrelate, and they may not always be present - but they are generally predominant.

\section{The Organisational Dimension}

Inevitably, in the modern and contemporary business and trading domain, large and significant organisations are involved and supply a structure for action - in particular companies, financial institutions and regulatory agencies. This essential context for business action gives rise to very challenging legal and ethical issues regarding agency and responsibility, and assessments of controlling action.

\section{The Business and Trading Environment}

Underlying any discussion of assessment and responsibility there is a recurring theme of justification and defence - that the business environment and the capitalist ethos are in some sense criminogenic. In particular, there are claims that the profit motive is naturally criminogenic, often leading to a defence of 
'normal' business behaviour, that 'everybody engages in the practice', as an expected part of business culture. Moreover, business activity may lead to an emotional detachment and a distance from human interpersonal relations: 'Tell Michael it was business, nothing personal' ${ }^{74}$ as a justification for attempted assassination.

\section{DEFINING CHARACTERISTICS OF DIRTY DEALING IN THE MARKETPLACE: THE DOMAIN OF THE TRICKSTER}

The discussion just above will hopefully have provided some elucidation of the essential subject matter here. As a significant form of economic delinquency, it is the domain of the trickster and joker rather than the thief. Importantly, it is possible to distinguish the method and impact of the thief (typically the highway robber or bandit, the pirate, the plunderer, the pickpocket and the burglar) and that of the economic trickster (typically engaging in fraud and deceit, collusion and conspiracy, bribery, exploitation, manipulation, fixing and rigging). Viewed in this way, the latter kind of economic dirty dealing or bad behaviour gives rise to some important problems and challenges. By its nature, it is less manifest and not so easily visible, and so more difficult in terms of identification, reporting and evidence. At the same time, evaluation and interpretation is less straightforward, leading to difficulties in normative and ethical assessment and policy decision-making. Put another way, the jurisprudence of acquisition by brute force involves less dilemma than that of acquisition by stealth. The task ahead is therefore to work out a convincing, consistent and clearly expressed theory and practice for the control and regulation of this more ambiguous and opaque species of economic delinquency.

74 Lines from the film Godfather III. 